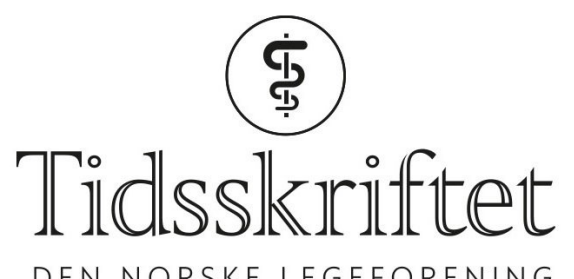

DEN NORSKE LEGEFORENING

\title{
Jermund Liljedal
}

MINNEORD

AUDUN MYSKJA

Jeg har i løpet av karrieren fått møte mentorer som har formet mitt virke som lege. Deres eksempel er en av de avgjørende grunnene til at jeg, som i utgangspunktet er på rask vei inn i formell pensjonsalder, kjenner en stadig økende drivkraft til legekallet og oppdraget som ligger i dypet av helsevesenet. Jermund Liljedal gikk bort 8. september 2019, 84 år gammel. Han var en slik mentor - og jeg vil takke han fra hjertet.

I de årene jeg arbeidet på Gravdal sykehus på midten og slutten av 1980-tallet, var Jermund Liljedal den ubestridte lederen. Liljedal var en lege av et sjeldent kaliber. I årene vi arbeidet sammen, kunne jeg lære av hans overlegne erfaring og skarpe innsikt. Jeg kan ikke huske at jeg så han gjøre en eneste større feilvurdering, selv i vanskelige og kompliserte tilfeller. En slik lege ønsket jeg å være. Men det viktigste med mentorer er ikke det faglige, men det menneskelige. Liljedal var etisk rettskaffen, inn til margen. Måten han alltid var engasjert i andre menneskers beste på, lever videre som en varig drivkraft.

Jeg kjenner meg særlig privilegert som har vært sykehuslege i en fase der vi aldri snakket om penger. Vi snakket om pasientene. Når alle var engasjerte og fokuserte på arbeidsoppgavene, var også sykefraværet lavt og budsjettene i balanse. Det var når vi begynte å snakke om penger og innsparinger, da Liljedals autoritative styring ble avløst av byråkrater uten erfaring fra pasientarbeid, at budsjettene sprakk.

Liljedal var et fyrtårn. Om han nå er gått bort, lever han like sterkt i meg og i andre som har fått merke hans eksempel, kunnskap og inspirasjon. Slik fungerer ekte mentorer. De er for evigheten.

Publisert: 24. februar 2020. Tidsskr Nor Legeforen. DOI: 10.4045/tidsskr.19.0763

(C) Tidsskrift for Den norske legeforening 2020. Lastet ned fra tidsskriftet.no 